\title{
Physical and Chemical Characterization of Fruits of Different Umbu (Spondias tuberosa) Accesses
}

\author{
Helena S. N. Santos ${ }^{1}$, Gisele P. Mizobutsi ${ }^{1}$, Juceliandy M. da S. Pinheiro ${ }^{1}$, José A. dos Santos Neto ${ }^{1}$, \\ Ariane Castricini ${ }^{2}$, Ignacio Aspiazú ${ }^{1}$, Carlos G. da Cruz ${ }^{1}$, Irisléia P. S. de Sousa ${ }^{1}$, \\ Mariana O. de Jesus ${ }^{1} \&$ Flávia S. Aguiar ${ }^{1}$ \\ ${ }^{1}$ Department of Agrarian Sciences, Faculdade de Agronomia, Universidade Estadual de Montes Claros, Janaúba, \\ Brazil \\ ${ }^{2}$ Empresa de Pesquisa Agropecuária de Minas Gerais (EPAMIG), Janaúba, Brazil \\ Correspondence: Helena S. N. Santos, Department of Agrarian Sciences, Faculdade de Agronomia, Universidade \\ Estadual de Montes Claros, Janaúba, Brazil. Tel: 55-389-9196-5630. E-mail: helenasns@hotmail.com
}

Received: June 6, 2019

Accepted: July 23, $2019 \quad$ Online Published: September 30, 2019

doi:10.5539/jas.v11n16p124

URL: https://doi.org/10.5539/jas.v11n16p124

\begin{abstract}
The umbuzeiro is a native Brazilian semi-arid plant with great agroindustrial potential. The characterization of the fruit, as well as the development or improvement of technologies for value aggregation are fundamental for its conservation, dissemination and culinary expansion. The objective was to characterize physically and chemically fruits of umbu and to define the access with greater commercial potential. A completely randomized design was used, with 10 replications, in a total of 4 accessions of umbuzeiro. The fruits were selected prioritizing uniformity of fruit size and maturation stage. Fruit peel color was analyzed; diameter and length; mass of the fruit, the bark, the pulp and the seed; firmness of the fruit, soluble solids contents; $\mathrm{pH}$; titratable acidity and solids/acidity ratio. The values of the pulp yield and the technological index were determined. Significance was verified for all variables, except for soluble solids and $\mathrm{pH}$. The average value of the titratable acidity was $1.3 \mathrm{mg}$ of citric acid $100 \mathrm{~mL}^{-1}$ of juice. The diameter of the fruits varied between 4.0 and $4.5 \mathrm{~cm}$. Fruit mass varied from 33.00 to $43.62 \mathrm{~g}$ and access to EPAMIG-C06 was the heaviest. The accesses EPAMIG-C06 and EPAMIG-C18 presented the highest technological index. Based on the results, it was concluded that the accesses present potential to the pulp industry due to the size and characteristics of the fruits. The umbu accesses under study presented small variation for solubility and $\mathrm{pH}$. For in natura consumption and/or processing, the access EPAMIG-C06 stands out due to attributes of commercial interest.
\end{abstract}

Keywords: Spondias tuberosa, post-harvest quality, physical-chemical analyzes

\section{Introduction}

The semi-arid region of Minas Gerais State, also known as "Faixa dos Gerais", is characterized by great climatic variability and vulnerability, which places it in the geographic space of the Brazilian semi-arid region. In general, municipalities located in the semi-arid suffer from the rigors of recurrent droughts, but present a variety of fruit species that play an important socioeconomic role for poor communities. However, these fruits are practically not commercially exploited (Brasil, 2005).

The fruits of the semi-arid region of Minas Gerais are little explored scientifically and still not very widespread in the consumer market, presenting exotic sensorial characteristics that arouse the interest of the consumers, as the flavor and aroma that make them potential candidates for exports, as well as alternatives for income generation, even in the domestic market (Gonçalves, 2008). However, even recognizing the richness in nutrients and the breadth of possibilities of using these fruits, they have not been receiving attention of researchers. There are few studies in the literature involving biometrics (Silva \& Filho, 2006) and the nutritional-chemical characterization of the fruits of this species and their storage (Oliveira et al., 2011), suggesting a great need for scientific investments in this regard. Biometric studies are used to for wide variety of species to assist the knowledge of the reproductive system to assist in breeding programs for non-domestic species (Moura, Chaves, \& Naves, 2013). 
The characterization of the fruits of the semi-arid region of Minas Gerais, as well as the development or improvement of value-added technologies, are fundamental for the conservation and dissemination of these products, allowing an expansion in national and international cuisine, and the use of native species with

high nutritional and functional potential can be an alternative for the social and economic development of local communities (Santos, Silva, Lacerda, Martins, \& Almeida, 2012).

Among the main fruits of the Minas Gerais semi-arid region, the umbu (Spondias tuberosa) stands out as an important source of income for the families of farmers in these regions. However, it is a fruit of short seasonal period and of high perishability, and as a consequence, waste occurs in the order of $50 \%$ of the production, due to the inadequate techniques of harvest, post-harvest and seasonality, being necessary the study on the quality (Silva, Martins, Alves, \& da Costa, 2016). Currently, fruits of the genus Spondias spp. are exploited in an extractive way, but present great agroindustrial potential due to their good sensorial characteristics, allowing to be consumed fresh or in the form of frozen pulp, juices, candies, popsicles and ice creams (E. D. P. A. Lima, C. A. A. Lima, Aldrigue, \& Godim, 2002; Junior et al., 2005; Gondim et al., 2013).

Currently, the fruits of the umbu have gained space in the national and international markets, since, besides presenting pleasant taste and peculiar aroma, they are a good source of bioactive compounds and their consumption can contribute substantially in human diets (Almeida et al., 2011). The physical and chemical characteristics of the fruits of the umbu are of great importance for adequate handling and commercialization and vary, besides the genetic factor, with location, crop practices, time of harvest and maturation stage (Santos, Cardoso, Fonseca, \& Conceição, 2010).

Research with the umbu has advanced mainly aiming the selection of clones with desirable agronomic characteristics, that is, clones with good productivity, with fruits weighing more than $20 \mathrm{~g}$, thin and smooth peel, and greater percentage of pulp and with a high content of soluble solids.

The development of this work is important in the expansion and enrichment of the information on the fruit of the umbu, aiming to enhance its cultivation and commercialization, preserve its genetic variability and its use in future breeding works, for example, to define the clone that best presents physical characteristics and chemical. Therefore, the objective was to characterize physically and chemically the fruits of different accesses of the umbuzeiro, Spondias tuberosa, as well as to define the access of greater commercial potential.

\section{Material and Methods}

\subsection{Accesses and Collection Site}

Fruits of Spondias Tuberosa were collected manually and in a randomized manner, in the "swelling" stage (Campos, 2007), which characterizes fruits at the beginning of physiological maturity. It was used fruits from four accessions, EPAMIG-C05, EPAMIG-C06, EPAMIG-C10, and EPAMIG-C18 (Moreira, Pimenta, Saturnino, Gonçalves, \& de Oliveira, 2007) (Table 1). Belonging to the active bank of umbuzeiro germplasm of the experimental area of Epamig, located in the city Nova Porteirinha, Minas Gerais $\left(15^{\circ} 47^{\prime} 29^{\prime \prime}\right.$ S- $\left.43^{\circ} 17^{\prime} 88^{\prime \prime} \mathrm{W}\right)$, with an average elevation of $500 \mathrm{~m}$, average annual rainfall of $800 \mathrm{~mm}$, and climate type Aw (Köppen).The soil of the area is characterized as Dystrophic Yellow Red Latosol (Santos, 2018).

Table 1. Origin and codes used by EPAMIG in the identification of accesses of umbuzeiro (Spondias tuberosa) prospected in the North of the State of Minas Gerais (Moreira, 2007)

\begin{tabular}{ll}
\hline $\mathrm{N}^{\circ}$ Code & Origin \\
\hline EPAMIG-C05 & Porteirinha \\
EPAMIG-C06 & Mamonas \\
EPAMIG-C10 & Januária \\
EPAMIG-C18 & Janaúba \\
\hline
\end{tabular}

Note. Identification of accesses of umbuzeiros of the active germplasm bank of EPAMIG and their respective origins.

The collected fruits were transported to the Laboratory of Post-Harvest Physiology and Technology of the State University of Montes Claros/Campus Janaúba, where a rigorous visual selection was carried out, in order to obtain more uniform lots, eliminating the fruits that presented any transport damage, in addition to standardization of maturity stage and uniformity of size. 
Afterwards, the fruits were washed in running water, and as an antifungal treatment, they were immersed in commercial sodium hypochlorite solution for $10 \mathrm{~min}$. They were then placed to dry under ambient conditions. A completely randomized design was used, with ten replicates and ten fruits per experimental unit. The access were evaluated for the color of the peel, using a color scale developed by Campos (2007) (Figure 1).

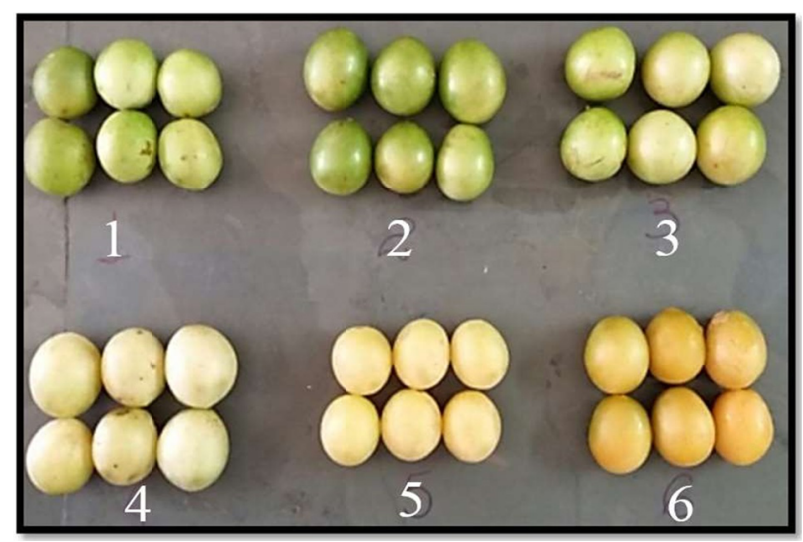

Figure 1. Standard color scale, numerical values assigned to the access based on the standard color scale of the collected fruits. 1: Totally green fruit; 2: Totally green fruit (semi mature); 3: Swollen green fruit; 4: Fruit with predominance of yellow; 5: Totally yellow fruit; 6: Totally yellow fruit (over mature)

\subsection{The Length and Diameter of the Fruits}

The length and diameter of the fruits were obtained with the aid of a digital caliper, and the results expressed in $\mathrm{cm}$. The firmness of the fruits was determined with a Brookfield CT3 benchtop analogue table texturometer, with a $4 \mathrm{~mm}$ diameter tip, in the median region of each fruit, and the results were expressed in $\mathrm{N}$. The fresh mass of peel, pulp and seeds of the fruits was determined with a semi-analytical scale, and the results expressed in g. Pulp yield was then determined, based on the equation:

$$
\mathrm{R}=\text { (Pulp mass/Fruit mass) } \times 100
$$

\subsection{Chemical Characteristics}

To obtain the chemical characteristics, the pulp of the fruits was ground with a manual processor (mixer) until homogenization. After that, the soluble solids content, $\mathrm{pH}$ and titratable acidity was evaluated.

\subsubsection{Soluble Solids}

The soluble solids were determined using a digital refractometer, in which the samples were read with a scale ranging from to $45^{\circ} \mathrm{Brix}$ (AOAC, 2005).

\subsubsection{Determination of $\mathrm{pH}$ and Titratable Acidity}

The $\mathrm{pH}$ was determined with the aid of a properly calibrated $\mathrm{pH}$ meter using a glass membrane potentiometer (AOAC, 2005), which was placed directly in contact with the $10 \mathrm{~g}$ sample of pulp, homogenized in $90 \mathrm{~mL}$ of distilled water, followed by $\mathrm{pH}$ reading.

The titratable acidity was determined according to the method recommended by the Adolfo Lutz Institute, (2008), using $10 \mathrm{~g}$ of the pulp diluted in $90 \mathrm{~mL}$ of distilled water, followed by titration with a standard solution of $0.1 \mathrm{M}$ $\mathrm{NaOH}$, using phenolphthalein as indicator. The result was expressed as $\mathrm{g}$ of citric acid per $100 \mathrm{~g}$ of sample.

\subsubsection{Technological Index (TI)}

The technological index (TI) was calculated with the values obtained of soluble solids and pulp yield, using the equation:

\subsection{Statistical Analysis}

$$
\mathrm{TI}=(\text { Soluble solids } \times \text { Pulp yield }) / 100
$$

The data collected were submitted to analysis of variance and the means were compared by the Tukey test at a $5 \%$ significance level. 


\section{Results and Discussion}

The access shows variations in color at the point of harvest, presenting different classification when compared to the standard color scale. Access EPAMIG-C10 presented the darker green coloration, to which was assigned a value of 2 in the color scale, followed by access EPAMIG-C05 and EPAMIG-C06 with values 4 and 3, respectively, with EPAMIG-C18 being the most yellow, classified in the color scale with the value of 5, totally yellow fruit. It is noteworthy that, even though presenting several color characteristics, the four accesses presented the same maturation pattern.

Table 2. Standard color scale for umbu fruits, harvested at EPAMIG's active germplasm bank in Nova Porteirinha-MG.

\begin{tabular}{lllll}
\hline Access & EPAMIG-C05 & EPAMIG-C06 & EPAMIG-C10 & EPAMIG-C18 \\
\hline Color scale & 4 & 3 & 2 & 5
\end{tabular}

Note. Numerical values attributed to the access based on the standard color scale of the collected fruits.

The diameters of the fruits oscillated between 4.0 and $4.5 \mathrm{~cm}$. Accesses that presented higher and lower means were access EPAMIG-C10 and access EPAMIG-C18, respectively (Table 3). These values are similar to those found by Pinheiro et al. (2015) and Dantas Junior (2008). Access EPAMIG-C06 had the longest length, followed by accesses EPAMIG-C05, EPAMIG-C10 and EPAMIG-C18 (Table 3). The values of the length are smaller than those of the diameter with a ratio close to one. This reflects that they are morphologically round or oval, a characteristic that makes them more suitable to the pulp industry, since the existing pulp machines are better suited to fruits with these dimensions.

Fruit mass varied from 33.00 to $43.62 \mathrm{~g}$ (Table 3) and the access to EPAMIG-C06 was the heaviest, statistically different from the others. The mean mass observed among the different accessions was $38.1 \mathrm{~g}$. In general, the fruit mass observed in this study was higher than that found by Dutra et al. (2017) in mature umbu fruits in five municipalities in the state of Bahia: Anagé (23.25 g), Belo Campo (22.75 g), Macarani (30.21 g), Caribbean $(23.70 \mathrm{~g})$, and Brumado $(18.81 \mathrm{~g})$. The mass of the fruits is an important characteristic during the in natura commercialization of umbu, because according to Santos et al. (2010), heavier fruits are also the largest, which are more attractive to consumers, and that is a determining factor for fruit marketing.

Peel mass is an important attribute for genetic improvement because it is associated with other characteristics that define fruit size, such as length and diameter, and which interfere with the consumer's preference. For this variable, values between 6.88 and $11.10 \mathrm{~g}$ were observed, with a mean of $9.2 \mathrm{~g}$ (Table 3). These values are similar to those obtained by Dantas Junior (2008) and Pinheiro et al. (2015). Accesses 5 and 10 are statically superior to the other evaluated accesses.

It is important to emphasize that, for the extraction of pulp from umbu fruits in industry, especially from semi-mature fruits, the peel is homogenized with the pulp itself, with no influence of its thickness on the industrial yield in quantitative terms, although it may influence on the quality of the product. However, for in natura consumption, a greater peel mass can result in greater resistance of the fruit, implying in a longer shelf life.

The greatest pulp mass was obtained in EPAMIG-C06, the others did not differ statistically from each other (Table 3). The mass of the pulp is directly related to the industrial yield of umbu, being preferred by the processing industries as well as the in natura consumption. The mean value found in this work for pulp mass was lower than that found by Pinheiro et al. (2015)-33.7 g.

There was a statistical difference for seed mass, with mean variations of 4.38 to $5.14 \mathrm{~g}$ among the accesses (Table 3). Access EPAMIG-C06 had the heaviest seeds, which corresponded to a percentage of $12.8 \%$ of the fruit weight. Dantas Júnior (2008), in studies with umbu fruits, obtained values of percentage of seed mass ranging from 7.23 to $13.7 \%$.

The firmness of the fruit differed among the evaluated accesses, with a general mean of approximately $43.8 \mathrm{~N}$ (Table 3). This mean was lower than the value found by Pinheiro et al. (2015), which was $63.5 \mathrm{~N}$ for the mature umbu fruits. However, EPAMIG-C18 presented higher firmness values, differing statistically from the others. Because of this value, the fruits of this clone are expected to have a longer post-harvest shelf life because of their greater resistance against physical and/or mechanical damage. It is worth mentioning that loss of firmness is associated with the increase of the hydrolyzing enzymes that degrade the carbohydrates of the cell wall. 
The yield of the pulp is a very important variable, since it is directly related to the industrial yield of the fruit. In the present study, it was observed that the mean pulp yield was $63.3 \%$, highlighting access EPAMIG-C06, which differed statistically from the others, showing the highest observed value (Table 3 ). The lowest percentage of pulp was obtained in access EPAMIG-C05, which did not differ statistically from access EPAMIG-C10 (Table $3)$.

Table 3. Fruits harvested from umbu access at EPAMIG's active germplasm bank in Nova Porteirinha-MG

\begin{tabular}{lllllllll}
\hline Access & LENG $(\mathrm{cm})$ & DIAM $(\mathrm{cm})$ & FM $(\mathrm{g})$ & PM $(\mathrm{g})$ & PLM $(\mathrm{g})$ & SM $(\mathrm{g})$ & $\mathrm{F}(\mathrm{N})$ & FY\% \\
\hline EPAMIG-C05 & $4.4 \mathrm{ab}$ & $3.9 \mathrm{~b}$ & $37.5 \mathrm{~b}$ & $11.1 \mathrm{a}$ & $21.6 \mathrm{~b}$ & $4.4 \mathrm{~b}$ & $47.4 \mathrm{~b}$ & $58.9 \mathrm{c}$ \\
PAMIG-C06 & $4.3 \mathrm{~b}$ & $4.1 \mathrm{a}$ & $43.6 \mathrm{a}$ & $7.9 \mathrm{~b}$ & $30.6 \mathrm{a}$ & $5.1 \mathrm{a}$ & $37.7 \mathrm{c}$ & $67.6 \mathrm{a}$ \\
EPAMIG-C10 & $4.5 \mathrm{a}$ & $3.7 \mathrm{c}$ & $38.2 \mathrm{~b}$ & $10.9 \mathrm{a}$ & $22.7 \mathrm{~b}$ & $4.6 \mathrm{~b}$ & $30.2 \mathrm{c}$ & $59.4 \mathrm{c}$ \\
EPAMIG-C18 & $4.0 \mathrm{c}$ & $3.7 \mathrm{c}$ & $33.0 \mathrm{~b}$ & $6.9 \mathrm{~b}$ & $19.9 \mathrm{~b}$ & $4.5 \mathrm{~b}$ & $59.8 \mathrm{a}$ & $63.8 \mathrm{~b}$ \\
Mean & 4.0 & 3.9 & 38.1 & 9.2 & 24.3 & 4.6 & 43.9 & 63.3 \\
CV (\%) & 2.3 & 3.4 & 12.3 & 10.2 & 15.8 & 10.5 & 17.4 & 4.6 \\
\hline
\end{tabular}

Note. Diameter (DIAM), length (LENG), fruit mass (FM), peel mass (PM), pulp mass (PLM), seed mass (SM), firmness (F) and fruit yield (FY). ** means followed by the same letter in the columns do not differ statistically by Tukey test $(5 \%)$.

According to Chitarra and Chitarra (2005), the proportion between the epicarp (peel), the mesocarp (pulp) and the endocarp (seed) indicates the production of raw material. In this sense, accesses EPAMIG-C05 and EPAMIG-C10 present two negative aspects regarding pulp yield. In addition to the smaller amount of pulp, they also presented high percentage of seeds and peel (Figure 2). Individual values varying from 58.9 to $67.6 \%$ were observed, and these values, both maximum and minimum, were close to those found by Saturnino, Gonçalves, \& Silva (2000), which characterized the fruits of the umbu in the State of Minas Gerais and verified a percentage of pulp ranging from $51.59 \%$ to $77.88 \%$, with an average of $64.73 \%$. Costa et al. (2015) verified a mean of $65.08 \%$ of pulp yield in fruits in the states of Paraíba and Rio Grande do Norte. All the evaluated accesses presented satisfactory characteristics for industrialization, with a mean yield percentage above $40 \%$, which is the minimum value stipulated by the Identity and Quality Standard (IQS) of the Ministry of Agriculture, Livestock and Supply (MAPA) (Brasil, 1999).

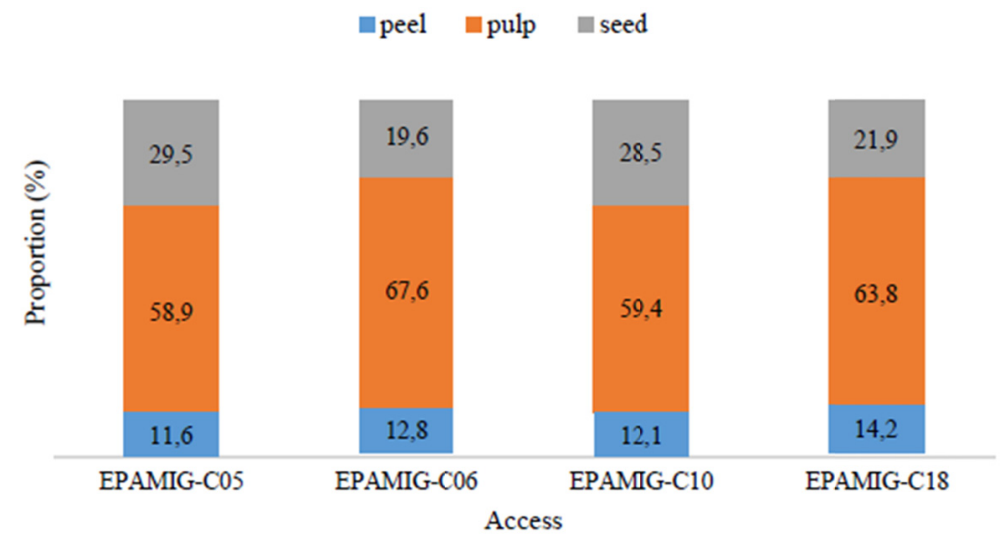

Figure 2. Peel, pulp and seed yield in fruits of different umbu access, harvested from the active germplasm bank of Nova Porteirinha-MG EPAMIG

Soluble solids contents (SS) of the fruits did not differ among the accesses, presenting a mean value of $9.1{ }^{\circ} \mathrm{Brix}$ (Table 4), similar to that found by Campos (2007) and Junior (2008). According to Costa, Luz, Gonçalves, and Bruno (2004) as the maturity stage of the umbu fruit progresses, soluble solids content also increases, reaching values of $7.0,8.5,9.5$, and $10.0^{\circ}$ Brix for the respective maturation stages of green, semi-mature, mature and with advanced maturation. For the umbu fruits considered as sweet, values of soluble solids of 7.3 were observed; 8.9; 10.1 and 10\%. According to Chitarra and Chitarra (2005), the soluble solids indicate the amount of solids 
that are dissolved in the juice or pulp of the fruits, being constituted mainly by sugars, which vary with the species, the cultivar, the stage of maturation and the climate, with values between 8 and $14 \%$.

There was no difference between the $\mathrm{pH}$ of the evaluated accesses (Table 4), only a small variation, ranging from 2.7 to 2.8, with an overall mean of 2.7, similar to those found by Lima, Dantas, Fonseca, and Barroso (2015) in studies with genotypes of species of the genus Spondias, that found variations in pH values from 2.39 to 2.63. The results similar to that observed by Ferreira, Duarte, MartinS, Ferreira, and Mizobutsi, (2015), who found pH readings ranging from 2.4 to 2.91. In fruit processing, low $\mathrm{pH}$ favors food preservation, decreasing development of microorganisms, but for in natura consumption, higher $\mathrm{pH}$ values are more accepted by consumers.

The soluble solids/titratable acidity ratio ranged from 6.4 to 7.9 , with the highest value observed in access EPAMIG-C06 (Table 4). The analyzes performed showed a mean of 7.1, superior to that described by Carvalho, Ritzinger, Soares Filho, and Ledo (2008) of 6.1 and by Menezes et al. (2017) of 4.82 in mature fruits. This ratio is one of the best ways of flavor evaluation, being more representative than the isolated measurement of sugars and acidity. This relationship has a direct influence on the consumer market. Brazilian consumer prefers higher values of this ratio, which are characterized by high soluble solids content and low acidity.

As for the Technological Index, the average found was 5.7 (Table 4), was similar to that reported by Lima et al. (2015), with a value of 6.99\%, in fruits of the genus Spondias. The EPAMIG-C06 and EPAMIG-C18 accessions had the highest technological index. These fruits are the most desirable, since they present greater possibility of concentration of soluble solids. Indexes technological applications of more than 4,4 are preferred by processing, since they indicate a greater possibility of sugar concentration, and the evaluation of the technology index is very employed in the most popular fruit processing industries such as orange and passion fruit (Sacramento, Matos, Souza, Barretto, \& Faria, 2007; Lima et al., 2015).

The titratable acidity showed a significant difference between the means, especially the EPAMIG-C06 and EPAMIG-C18 accesses (Table 4). The mean value found was $1.3 \mathrm{mg}$ of citric acid $100 \mathrm{~mL}^{-1}$ of juice, lower than the values found by Menezes et al. (2017), who observed a value of $2.12 \%$ in mature fruits, and by Dutra et al. (2017) who verified values varying between 1.84 and $2.91 \%$. Generally, in fruits of the Spondia genus, titratable acidity with values greater than 1 and less than $2 \%$ are preferred by industry, because under these conditions there is no need to apply acids for preservation of fruit pulp (Carvalho et al., 2008).

Table 4. Soluble solids content (SS), $\mathrm{pH}$, soluble solids/titratable acidity ratio (SS/TA ratio), technological index (TI) and titratable Acidity (TA) of fruits of different umbu accesses, collected from the active germplasm bank of EPAMIG, Nova Porteirinha-MG

\begin{tabular}{|c|c|c|c|c|c|}
\hline Access & SS $\left({ }^{\circ}\right.$ Brix $)$ & $\mathrm{pH}$ & SS/TA Ratio & TI & TA (mg $100 \mathrm{~g}^{-1}$ citric acid) \\
\hline EPAMIG-C05 & 8.9 & 2.8 & $6.6 \mathrm{~b}$ & $5.2 b$ & $1.4 \mathrm{a}$ \\
\hline EPAMIG-C06 & 8.9 & 2.7 & $7.9 \mathrm{a}$ & $6.2 \mathrm{a}$ & $1.2 \mathrm{~b}$ \\
\hline EPAMIG-C10 & 9.2 & 2.7 & $6.4 \mathrm{~b}$ & $5.4 b$ & $1.4 \mathrm{a}$ \\
\hline EPAMIG-C18 & 9.3 & 2.8 & $7.4 \mathrm{ab}$ & $6.1 \mathrm{a}$ & $1.3 \mathrm{ab}$ \\
\hline Mean & 9.1 & 2.7 & 7.1 & 5.7 & 1.3 \\
\hline CV (\%) & 5.7 & 2.4 & 13.8 & 8.3 & 11.4 \\
\hline
\end{tabular}

Note. Means followed by the same letter in the columns do not differ statistically by Tukey test (5\%).

\section{Conclusions}

All studied accessions are morphologically oval and have little variations of $\mathrm{pH}$ and total soluble solids content.

The EPAMIG-C18 access presented higher values of firmness, thus, it is expected that the fruits have a longer post-harvest shelf life.

All the accesses evaluated presented satisfactory characteristics for industrialization, with an average yield percentage above $40 \%$.

EPAMIG-C06 access is characterized by higher mass, high percentage of pulp, high SS/TA ratio and higher technological index for in natura consumption and/or processing.

\section{References}

Adolfo, L. (2008). Métodos físico-químicos para análise de alimentos (4th ed.). São Paulo, SP: Instituto Adolfo Lutz. 
Almeida, M. M. (1999). Armazenagem refrigerada de umbu (Spondia tuberosa Arruda Câmara): Alterações das características fisicas e químicas de diferentes estádios de maturação (Unpublished Master Thesis, Universidade Federal da Paraíba, Campina Grande, Brazil).

Almeida, M. M. B., de Sousa, P. H. M., Arriaga, Â. M. C., do Prado, G. M., Magalhães, C. E., Maia, G. A., \& de Lemos, T. L. G. (2011). Bioactive compounds and antioxidant activity of fresh exotic fruits from northeastern Brazil. Food Research International, 44(7), 2155-2159. https://doi.org/10.1016/j.foodres. 2011.03.051

AOAC. (2005). Official methods of analysis (18th ed.). Gaithersburg, MD, USA.

Brasil. (2005). Instrução Normativa $n^{\circ} 122$, de 10 de setembro de 1999. Brasília, DF: Ministério da Agricultura, Pecuária e do Abastecimento.

Campos, C. de O. (2007). Frutos de umbu (Spondias tuberosa Arruda): Características fisico-químicas durante seu desenvolvimento e na pós-colheita (Doctoral dissertation, Universidade Estadual Paulista, Faculdade de Ciências Agronômicas). Retrieved from http://hdl.handle.net/11449/103228

Carvalho, P. C. L., Ritzinger, R., Soares Filho, W. dos S., \& Ledo, C.A.S. (2008). Características morfológicas, físicas e químicas de frutos de populações de umbu-cajazeira no Estado da Bahia. Revista Brasileira de Fruticultura, 30(1), 140-147. https://doi.org/10.1590/S0100-29452008000100026

Chitarra, M. I. F., \& Chitarra, A. D. (2005). Pós-colheita de frutas e hortaliças: Fisiologia e manuseio (2nd ed.). Lavras: UFLA.

Costa, N. P., Luz, T. L. L. B., Gonçalves, E. P., \& Bruno, R. de L. A. (2004). Caracterização físico-química de frutos de umbu (Spondias 200 tuberosa ARR. CÂM.) colhidos em quatro estádios de maturação. Bioscience 201 Journal, 20(2), 65-71.

Costa, F. R., Rêgo, E. R., Rêgo, M. M., Neder, D. G., Silva, S. M., \& Schunemann, A. P. P. (2015). Análise biométrica de frutos de umbuzeiro do semiárido Brasileiro. Bioscience Journal, 31(3), 682-690. https://doi.org/10.14393/BJ-v31n3a2015-22844

Dantas Junior, O. R. (2008). Qualidade e capacidade antioxidante total de frutos de clones de umbu oriundos do semi-árido nordestino (Unpublished Master Thesis, Universidade Federal da Paraíba, Areia, Brazil).

Dutra, F. V., Cardoso, A. D., Morais, O. M., Viana, A. E. S., Melo, T. L., \& Júnior, N. D. S. C. (2017). Características físicas e químicas de acessos de umbuzeiros (Spondias tuberosa Arr. Cam). Revista de Ciências Agrárias, 40(4), 140-149. https://doi.org/10.19084/RCA17027

Ferreira, L. B., Duarte, A. B., Martins, J. C., Ferreira, A. F., \& Mizobutsi, G. P. (2015). Caracterização fisico-química de frutos de umbuzeiro (Spondias tuberosa Arr. Câm.) de Janaúba-MG. Paper presented at the Brazilian Congress on Minimal Processing and Post-harvesting of Fruits, Flowers and Vegetables, Aracaju, SE. Retrieved from http://octeventos.com/site/sites/pos-colheita/anais/PDF/00244_032231.pdf

Folegatti, M. I. S., Matsuura, F. C. A. U., Cardoso, R. L., Machado, S. S., Rocha, A. S., \& Lima, R. R. (2003). Aproveitamento industrial do umbu: processamento de geléia e compota. Ciência Agrotecnologia, 27(6), 1308-1314. https://doi.org/10.1590/S1413-70542003000600015

Gonçalves, A. E. S. S. (2008). Avaliação da capacidade antioxidante de frutas e polpa de frutas nativas e determinação de teores de flavonoides e vitamina (Unpublished Master Thesis, Universidade de São Paulo, São Paulo, Brazil).

Gondim, P. J., Silva, S. de M., Pereira, W. E., Dantas, A. L., Chaves Neto, J. R., \& dos Santos, L. F. (2013). Qualidade de frutos de acessos de umbu-cajazeira (Spondias sp.). Revista Brasileira de EngenhariaAgricola e Ambiental-Agriambi, 17(11), 1217-1221. https://doi.org/10.1590/S1415-43662013001100013

Lima, E. D. P. A., Lima, C. A. A., Aldrigue, M. L., \& Godim, P. J. S. (2002). Umbu-cajá (Spondias spp.) aspectos de pós-colheita e processamento. João Pessoa, PE: Ed Universitária/Ideia.

Lima, M. S. S., Dantas, A. C. V. L., Fonseca, A. A. O., \& Barroso, J. P. (2015). Caracterização de frutos de genótipos selecionados de umbu-cajazeira (Spondias sp.). Interciencia, 40(5), 311-316.

Lira Júnior, J. S., Musser, R. dos S., Melo, E. de A., Sucupira, M. I. M., Lederman, I. E., \& dos Santos, V. F. (2005). Caracterização física e físico-química de frutos de cajá-umbu (Spondias spp.). Ciência e Tecnologia de Alimentos, 25(4), 757-761. https://doi.org/10.1590/S0101-20612005000400021 
Menezes, P. H. S., de Souza, A. A., da Silva, E. S., de Medeiros, R. D., Barbosa, N. C., \& Soria, D. G. (2017). Influência do estádio de maturação na qualidade físico-química de frutos de umbu (Spondias tuberosa). Scientia Agropecuaria, 8(1), 73-78. https://doi.org/10.17268/sci.agropecu.2017.01.07

Moura, N. F., Chaves, L. J., \& Naves, R. V. (2013). Caracterização física de frutos de pequizeiro (Caryocar brasiliense Camb) do cerrado. Revista Árvore, 37(5), 905-912. https://doi.org/10.1590/S0100-67622013 000500013

Moreira, P. de A., Pimenta, M. A. S., Saturnino, H. M., Gonçalves, N. P., \& de Oliveira, D. A. (2007). Variabilidade genética de umbuzeiro na região Norte do Estado de Minas Gerais. Revista Brasileira de Biociências, 5(1), 279-281.

Oliveira, M. D., Santana, D. D., \& Santos, C. M. (2011). Biometria de frutos e sementes e emergência de plântulas de duas espécies frutíferas do gênero Campomanesia. Revista Brasileira de Fruticultura, 33(2), 446-455. https://doi.org/10.1590/S0100-29452011005000069

Pinheiro, J. M. da S.; Rodrigues, M. L. M., Fonseca, S. N. A., Paraiso, E., A., Mizobutsi, G. P., \& Lopes, E. P. (2015). Caracterização física e química de frutos de umbu. Paper presented at the Brazilian Congress on Minimal Processing and Post-harvesting of Fruits, Flowers and Vegetables, Aracaju, SE. Retrieved from http://octeventos.com/site/sites/pos- colheita/anais/PDF/00244_032231.pdf

Pinto, W. D. S., Dantas, A. C. V. L., Fonseca, A. A. O., Ledo, C. A. D. S., Jesus, S. C. D., Calafange, P. L. P., \& Andrade, E. M. (2003). Caracterização física, físico-química e química de frutos de genótipos de cajazeiras. Pesquisa Agropecuária Brasileira, 38(9), 1059-1066. https://doi.org/10.1590/S0100-204X2003000900006

Sacramento, C. D., Matos, C. B., Souza, C. N., Barretto, W. S., \& Faria, J. C. (2007). Características físicas, físico-químicas e químicas de cajás oriundos de diversos municípios da região sul da Bahia. Magistra, 19(4), 283-289.

Saturnino, H. M., Gonçalves, N. P., \& Silva, E. de B. (2000). Informações sobre a cultura do umbu. Nova Porteirinha, MG: EPAMIG-CTNM.

Santos, G. G., Silva, M. R., Lacerda, D. B. C. L., Martins, D. M. de O., \& Almeida, R. A. (2012). Aceitabilidade e qualidade físico-química de paçocas elaboradas com amêndoa de baru. Pesquisa Agropecuária Tropical, 42(2), 10-1590. https://doi.org/10.1590/S1983-40632012000200003

Santos, M. B. D. U., Cardoso, R. L., Fonseca, A. A. D. O., \& Conceição, M. D. N. U. (2010). Caracterização e qualidade de frutos de umbu-cajá (Spondias tuberosa $\times$ S. mombin) provenientes do recôncavo sul da Bahia. Revista Brasileira de Fruticultura, 32(4), 1089-1097. https://doi.org/10.1590/S0100-29452011005000015

Santos, H. G. (2018). Caracterização dos frutos do umbu. Sistema Brasileiro de Classificação de Solos (5th ed.). Petrolina, PE: EMBRAPA-CPATSA.

Silva, M. A. P., \& Filho, S. M. (2006). Morfologia de fruto, semente e plântula de piqui (Caryocar coriaceum Wittm.). Revista Ciência Agronômica, 37(3), 320-325.

Silva, M. I., Martins, J. N., Alves, J. E. de A., \& da Costa, F. F. P. (2016). Caracterização físico-química da polpa de umbu em camada de espuma. Revista Semiárido De Visu, 3(2), 82-91.

\section{Copyrights}

Copyright for this article is retained by the author(s), with first publication rights granted to the journal.

This is an open-access article distributed under the terms and conditions of the Creative Commons Attribution license (http://creativecommons.org/licenses/by/4.0/). 